\title{
IMPLEMENTASI KURIKULUM 2013 EDISI REVISI DALAM PEMBELAJARAN MEMBACA PUISI (STUDI KASUS DI KELAS X IPS 1 SMA NEGERI 1 KARANGANYAR)
}

\author{
Nofi Dian Sari, Budhi Setiawan, Yant Mujiyanto \\ Universitas Sebelas Maret \\ Surel: nofidiansari@student.uns.ac.id
}

\begin{abstract}
Abstrak: Penelitian ini merupakan penelitian kualitatif dengan pendekatan studi kasus. Populasi dalam penelitian ini adalah siswa kelas X SMA Negeri 1 Karanganyar. Sampel penelitian yaitu siswa kelas X IPS 1 dengan teknik pengambilan sampel purposive sampling. Sumber data meliputi peristiwa, informan, dan dokumen. Teknik pengumpulan data berupa observasi, wawancara, dan analisis dokumen. Uji validitas data terdiri dari triangulasi sumber data, triangulasi metode, dan review informan. Teknik analisis data yaitu model analisis interaktif (interactive model of analysis). Hasil penelitian ini meliputi: (1) persepsi guru terhadap implementasi Kurikulum 2013 Edisi Revisi pada pembelajaran membaca puisi sudah baik; (2) perencanaan pembelajaran disusun sesuai dengan Permendikbud Nomor 22 Tahun 2016; (3) pelaksanaan pembelajaran membaca puisi berjalan dengan cukup baik; (4) penilaian pembelajaran belum dilakukan secara efektif; (5) hambatan berupa: (a) waktu tatap muka pembelajaran di semester 2 yang terbatas; (b) pelaksanaan penilaian pembelajaran yang kurang efektif; (c) tidak semua siswa memiliki bakat membaca puisi dan siswa sulit menemukan suasana puisi; (d) subjektivitas dalam menilai pembelajaran sastra; (6) upaya berupa: (a) pemberian tugas secara terstruktur maupun tak terstruktur; (b) penggunaan tugas secara diskusi kelompok agar penilaian membaca puisi tetap bisa dilaksanakan secara keseluruhan; (c) siswa diharuskan untuk sering melihat referensi penampilan membaca puisi dari youtube; d) pembuatan kriteria penilaian.
\end{abstract}

Kata Kunci: implementasi kurikulum, Kurikulum 2013 Edisi Revisi, pembelajaran membaca puisi

\section{IMPLEMENTATION OF 2013 CURRICULUM REVISION EDITION IN READ POETRY LEARNING (CASE STUDY IN CLASS X IPS 1 OF SENIOR HIGH SCHOOL 1 KARANGANYAR)}

\begin{abstract}
This research is a qualitative research with case study approach. The population in this study were class X students of SMA Negeri 1 Karanganyar. The research sample was students of class X IPS 1 with purposive sampling sampling technique. Data sources include events, informants, and documents. Data collection techniques such as observation, interview, and document analysis. The data validity test consists of triangulation of data sources, method triangulation, and informant review. Data analysis technique is interactive model of analysis. The results of this study include: (1) teachers' perceptions of the implementation of the Curriculum 2013 Revised Edition on learning to read poetry is good; (2) instructional planning is prepared in accordance with Permendikbud Number 22 Year 2016; (3) the implementation of reading poetry learning works well; (4) assessment of learning has not been done effectively; (5) obstacles in the form of: (a) limited face-to-face learning time in semester 2; (b) the implementation of a less effective learning assessment; (c) not all students have the talent to read poetry and students find it difficult to find the atmosphere of poetry; (d) subjectivity in assessing literary learning; (6) efforts in the form of: (a) providing structured and unstructured tasks; (b) the use of tasks in group discussion so that the assessment of poetry reading can still be carried out in its entirety; (c) students are required to frequently see references to reading poetry from youtube; d) making assessment criteria.
\end{abstract}

Keywords: curriculum implementation, Curriculum 2013 Revised Edition, reading poetry learning

BASASTRA Jurnal Bahasa, Sastra, dan Pengajarannya

Volume 6 Nomor 2, Oktober 2018, ISSN 2302-6405 


\section{PENDAHULUAN}

Pendidikan di Indonesia mulai berbenah. Kementerian Pendidikan dan Kebudayaan (Kemendikbud) mulai melakukan perubahan demi kemajuan pendidikan di Indonesia yang lebih baik. Perubahan yang tampak jelas dan menimbulkan pro serta kontra di hampir semua kalangan yaitu perubahan terhadap kurikulum pendidikan.

Perubahan terhadap kurikulum dilakukan seiring dengan perkembangan zaman yang semakin canggih dan kompleks. Pemerintah menyadari bahwa tantangan yang akan dihadapi beberapa tahun ke depan jauh lebih berat. Salah satu modal untuk menghadapi persaingan di dunia internasional yaitu dengan cara menyiapkan para generasi penerus bangsa yang cerdas, mampu beradaptasi dengan segala macam perubahan, dan berkarakter. Semua harapan tersebut dapat dimulai dan direalisasikan melalui perbaikan terhadap suatu sistem pendidikan.

Kurikulum 2013 ditetapkan sebagai kurikulum baru dalam pendidikan di Indonesia. Kurikulum 2013 menggantikan kurikulum yang berlaku pada tahun-tahun sebelumnya yaitu Kurikulum Tingkat Satuan Pendidikan (KTSP). Kurikulum 2013 diharapkan mampu menghasilkan generasi penerus bangsa yang memiliki jiwa produktif, kreatif, inovatif, dan afektif. Penguatan aspek sikap, pengetahuan, dan keterampilan juga menjadi perhatian khusus dalam Kurikulum 2013. Kemendikbud mengharapkan ketiga aspek tersebut dapat terpenuhi satu sama lain. Para siswa yang memiliki pengetahuan atau kecerdasan yang tinggi namun tidak disertai dengan sikap yang baik serta tidak mampu mengimplementasikan pengetahuannya dalam kehidupan bermasyarakat, maka pengetahuan tersebut belum dianggap sempurna atau belum bermanfaat. Perkembangan zaman yang semakin kompleks mendorong perlunya perubahan terhadap kurikulum, Abidin (2014: 11) mengatakan bahwa Kurikulum 2013 merupakan kurikulum yang diberlakukan dengan tujuan untuk menghasilkan lulusan yang kompetitif, inovatif, kreatif, kolaboratif serta berkarakter sehingga dapat menjadi sarana dalam menghadapi tantangan global dalam hal pendidikan.

Karakter menjadi salah satu hal yang menjadi perhatian dalam Kurikulum 2013. Hal yang mendasari pernyataan tersebut yaitu semakin banyak kasus kekerasan dan pergaulan bebas yang melibatkan generasi muda bangsa, maka berkarakter dalam Kurikulum 2013 diharapkan mampu mengurangi masalah-masalah tersebut dan membenahi proses pendidikan di Indonesia.

Kurikulum 2013 membawa beberapa perubahan dalam proses pelaksanaan pembelajaran. Perubahan tersebut antara lain penghilangan standar kompetensi yang diganti dengan penggunaan istilah kompetensi inti dan kompetensi dasar, perombakan format Rencana Pelaksanaan Pembelajaran (RPP), format penilaian yang lebih kompleks, disediakan buku induk pegangan guru dan siswa dari pemerintah, guru hanya bertindak sebagai fasilitator, serta siswa lebih banyak berpartisipasi dalam keaktifan di dalam kelas. Segala bentuk perubahan memerlukan proses panjang agar dapat dilaksanakan sesuai dengan tujuan yang telah ditetapkan. Perubahan dalam kurikulum tersebut memberikan pengaruh yang besar dalam proses pembelajaran.

Pembelajaran pada Kurikulum 2013 mendorong para siswa untuk dapat melakukan pengamatan, bertanya, menalar, dan mengomunikasikan pengetahuan yang mereka dapat selama proses pembelajaran. Pendekatan saintifik menjadi pendekatan yang digunakan dalam tiap pembelajaran. Selain pendekatan saintifik, adapula pembelajaran berbasis teks dalam Kurikulum 2013 yang diharapkan dapat meningkatkan literasi siswa dalam proses pembelajaran.

Dalam pembelajaran bahasa Indonesia di tingkat Sekolah Menengah 
Atas (SMA) disediakan berbagai jenis pembelajaran berbasis teks dengan berbagai genre. Pembelajaran bahasa Indonesia berbasis teks di kelas $\mathrm{X}$ antara lain, teks laporan hasil observasi, teks eksposisi, teks anekdot, teks cerita rakyat, teks negosiasi, teks debat, teks biografi, dan teks puisi. Berbagai jenis teks tersebut memiliki ciri khas dan tingkat kesulitan berbeda-beda yang harus dipahami oleh siswa.

Pembelajaran berbasis teks memberikan manfaat bagi pembelajaran bahasa Indonesia. Empat keterampilan berbahasa dapat berkembang lebih baik melalui sistem pembelajaran tersebut, karena para siswa dituntut untuk selalu berhubungan dengan bacaan atau teks. Melalui pembelajaran bahasa Indonesia, para siswa diharapkan dapat mengembangkan empat keterampilan berbahasa. Empat keterampilan berbahasa tersebut yaitu mendengarkan, berbicara, membaca, dan menulis. Keempat keterampilan berbahasa memiliki pengaruh yang cukup besar bagi kehidupan siswa ketika mengikuti pembelajaran di dalam kelas maupun di kehidupan bermasyarakat.

Kurikulum 2013 memberikan ruang yang luas bagi pembelajaran bahasa Indonesia untuk mengembangkan empat keterampilan berbahasa tersebut. Dalam Kurikulum 2013, para siswa dituntut untuk lebih aktif berpendapat di dalam kelas sehingga meningkatkan kemampuan berbicara siswa. Selain mahir dalam mengungkapkan pendapat, para siswa juga dituntut untuk dapat menghargai pendapat teman sejawat sehingga keterampilan mendengarkan juga dapat terasah. Pembelajaran berbasis teks secara tidak langsung dapat mengembangkan kemampuan membaca dan menulis bagi siswa, karena semakin banyak menyerap informasi dari kegiatan membaca maka semakin baik pula kemampuan menulis. Ide atau kreativitas dapat muncul saat kegiatan membaca dan mendorong siswa untuk terampil menuangkan ide atau kreativitasnya ke dalam sebuah tulisan.
Keempat keterampilan berbahasa tersebut memiliki keunggulan masingmasing, tidak ada yang dapat dikatakan lebih baik. Namun keterampilan berbahasa tersebut masih diabaikan oleh para siswa maupun masyarakat, salah satunya pada keterampilan membaca. Membaca merupakan suatu kegiatan mencari dan memahami informasi dari bacaan yang dibaca. Kegiatan membaca dapat memberi pengaruh positif antara lain wawasan maupun ilmu pengetahuan bertambah dan dapat memahami pola pikir seseorang melalui tulisan orang tersebut. Dalam pembelajaran pada Kurikulum 2013 diharapkan siswa mampu berliterasi melalui kegiatan membaca berbagai referensi bacaan. Namun kegiatan berliterasi tersebut, siswa tidak hanya sekadar membaca tetapi diharapkan mampu memahami maksud dari bacaan sehingga dapat mengomunikasikan informasi yang terdapat dalam bacaan tersebut kepada orang lain.

Kegiatan membaca bukan hal yang mudah. Para siswa masih mengalami kesulitan dalam kegiatan membaca terutama pada aspek memahami isi bacaan. Tujuan utama dari kegiatan membaca yaitu untuk menemukan dan memahami isi yang terdapat dalam bacaan. Pembelajaran bahasa Indonesia berbasis teks terdiri dari berbagai materi teks bacaan. Salah satunya yaitu teks sastra. Teks sastra memiliki ciri khas yang membedakannya dengan dengan teks bacaan lain yaitu pada penggunaan bahasa. Teks sastra tidak terikat oleh aturan baku yang diatur dalam Pedoman Umum Ejaan Bahasa Indonesia (PUEBI). Namun hal ini ternyata justru membuat teks sastra sulit dipahami oleh para pembaca, tidak terkecuali bagi para siswa karena teks sastra banyak menggunakan bahasa kiasan. Salah satu karya sastra yang paling banyak menggunakan bahasa kiasan yaitu puisi.

Kegiatan membaca terutama membaca puisi menjadi sesuatu yang dianggap sulit bagi sebagian siswa. Hal ini menuntut guru untuk membuat proses 
pembelajaran membaca puisi lebih menyenangkan dan mudah diikuti oleh para siswa. Puisi merupakan salah satu karya sastra yang berupa kumpulan katakata yang indah. Puisi menggunakan katakata yang bersifat konotasi. Pemakaian majas menjadi ciri dari puisi. Oleh sebab itu, pesan atau makna yang ada dalam sebuah puisi cenderung bersifat tersirat. Para siswa perlu mengapresiasi secara mendalam untuk menemukan isi dan pesan yang ingin disampaikan oleh penulis.

Pembelajaran membaca puisi diharapkan mampu membentuk jiwa bersastra dalam diri siswa. Pembelajaran membaca puisi juga mendorong siswa untuk mengenal lebih dalam mengenai karya-karya sastra. Dalam pembelajaran tersebut, siswa diajak mengenal karyakarya dari para penyair hebat Indonesia dan berupaya untuk dapat membacakan sebuah karya sastra berupa puisi. Siswa diajak untuk lebih mengasah kepekaannya melalui karya sastra. Pembelajaran membaca puisi tidak terlepas dari pembelajaran sastra, Basir mengatakan bahwa dalam kurikulum 2013 secara tersurat dijelaskan bahwa pembelajaran sastra bertujuan agar siswa dapat menikmati dan memanfaatkan karya sastra untuk memperluas wawasan, budi pekerti, serta meningkatkan pengetahuan dan kemampuan berbahasa, dan menghargai dan membanggakan sastra Indonesia sebagai khazanah budaya dan intelektual manusia Indonesia. Sastra juga memiliki peran dalam membentuk karakter siswa. Pembelajaran puisi menjadikan pembelajaran bahasa Indonesia lebih berwarna. Namun Kurikulum 2013 yang bersifat pembelajaran berbasis saintifik memberikan proses pembelajaran yang berbeda pada proses pembelajaran sastra terutama pembelajaran membaca puisi.

Dalam kurikulum tidak hanya berisi suatu perencanaan dalam pembelajaran, namun diperlukan implementasi dari rencana-rencana yang telah dituliskan, Kurniasih \& Berlin S. (2014: 5) mengatakan bahwa implementasi kurikulum adalah suatu upaya untuk menerapkan sebuah kurikulum yang telah dirancang secara sistematis dan terencana. Implementasi Kurikulum 2013 terutama dalam pembelajaran bahasa Indonesia masih mengalami beberapa kendala dalam pelaksanaannya. Tuntutan dan harapan yang begitu banyak dalam Kurikulum 2013 belum dapat terpenuhi secara langsung. Guru dan siswa yang menjadi salah satu pemain utama dalam implementasi Kurikulum 2013 tersebut mengalami beberapa situasi yang belum pernah mereka bayangkan sebelumnya. Proses pembelajaran yang sangat berbeda membuat mereka harus belajar lebih keras. Pada akhirnya, pemerintah melakukan revisi terhadap Kurikulum 2013 tersebut.

Sejak diberlakukan, Kurikulum 2013 telah digunakan di berbagai sekolah di Indonesia meskipun ada beberapa sekolah yang belum menggunakan kurikulum tersebut. SMA Negeri 1 Karanganyar menjadi salah satu sekolah yang telah menerapkan kurikulum tersebut. SMA Negeri 1 Karanganyar merupakan salah satu SMA rujukan di wilayah Karanganyar. Hal tersebut dilatarbelakangi oleh segala prestasi yang telah diraih oleh para siswa di SMA Negeri 1 Karanganyar, sehingga menambah daya kepercayaan di hati masyarakat untuk menyekolahkan putra-putri mereka di sekolah tersebut. Para siswa di SMA Negeri 1 Karanganyar merupakan siswa-siswi yang mempunyai intelektual yang baik. Karakter yang ditampilkan oleh para siswa juga mencerminkan karakter yang sopan dan santun dalam bersikap maupun bertutur. Hal ini membuat peneliti ingin mengetahui upaya implementasi kurikulum dalam pelaksanaan pembelajaran yang dilakukan oleh guru.

Kurikulum 2013 telah berjalan kurang lebih selama 5 tahun, waktu yang masih sangat singkat untuk mencapai sebuah tujuan pendidikan yang kompleks. Pelaksanaan Kurikulum 2013 tidak secara langsung memberikan hasil yang sempurna, namun secara bertahap 
memberikan perubahan yang positif bagi pelaksanaan pendidikan di Indonesia. Kurikulum 2013 selalu berbenah untuk memperbaiki kekurangan atau masalahmasalah yang muncul dalam pelaksanaannya. Kurikulum 2013 pun mengalami tahap revisi untuk memperbaiki sistem pelaksanaannya. Revisi yang dilakukan memunculkan perubahan pada beberapa aspek. Berdasarkan pembahasan di atas, maka dalam penelitian ini akan dibahas tentang implementasi Kurikulum 2013 Edisi Revisi dalam pembelajaran membaca puisi (studi kasus di kelas X IPS 1 SMA Negeri 1 Karanganyar).

\section{METODE PENELITIAN}

Penelitian ini merupakan penelitian kualitatif dengan menggunakan pendekatan studi kasus. Penelitian kualitatif digunakan untuk mendeskripsikan suatu peristiwa tertentu berdasarkan kenyataan yang sebenarnya melalui sebuah pengamatan langsung. Pendekatan studi kasus dipilih karena pada penelitian ini hanya berfokus pada satu masalah atau peristiwa dalam satu kelas yaitu pada implementasi Kurikulum 2013 Edisi Revisi dalam pembelajaran membaca puisi (studi kasus di kelas X IPS 1 SMA Negeri 1 Karanganyar). Metode yang digunakan yaitu metode deskriptif kualitatif dengan tiga tahap penelitian yaitu penyediaan data, analisis data, dan penyajian hasil analisis data. Data dalam penelitian ini bersumber dari peristiwa pelaksanaan pembelajaran membaca puisi di kelas $X$ IPS 1 SMA Negeri 1 Karanganyar. Sumber data yang digunakan bersumber dari peristiwa, informan, dan dokumen pendukung. Teknik pengambilan sampel penelitian yang digunakan yaitu purposive sampling. Populasi dalam penelitian ini adalah siswa kelas X SMA Negeri 1 Karanganyar. Sampel yang dipilih adalah kelas X IPS 1 SMA Negeri 1 Karanganyar. Teknik pengumpulan data yang digunakan yaitu observasi, wawancara, dan analisis dokumen. Teknik uji validitas data yang digunakan yaitu triangulasi sumber data, triangulasi metode, dan review infoman. Teknik analisis data yang digunakan dalam penelitian ini yaitu model analisis interaktif (interactive model of analysis). Model ini dipilih karena data yang digunakan berupa peristiwa pembelajaran.

\section{HASIL DAN PEMBAHASAN}

Penelitian ini mendeskripsikan hasil temuan penelitian tentang implementasi Kurikulum 2013 Edisi Revisi dalam pembelajaran membaca puisi yang dilaksanakan di kelas X IPS 1 SMA Negeri 1 Karanganyar. Hasil dan pembahasan dalam penelitian ini sebagai berikut.

\section{Persepsi Guru terhadap Implementasi Kurikulum 2013 Edisi Revisi dalam Pembelajaran Membaca Puisi}

Ada banyak hal yang perlu diperhatikan seorang guru dalam menjalankan peran sebagai seorang pendidik. Ada sejumlah proses yang harus dipenuhi guru sebelum siap masuk ke dalam kelas untuk melakukan kegiatan belajar mengajar. Kegiatan perencanaan pembelajaran, pelaksanaan pembelajaran, dan penilaian pembelajaran merupakan hal yang wajib dipahami oleh guru. Maka memahami segala tugas sebagai seorang guru tersebut menjadi hal yang penting untuk kelancaran proses pembelajaran. Hal ini seperti diungkapkan oleh Mulyasa (2014: 41) yang mengatakan bahwa guru merupakan faktor penting yang memiliki pengaruh besar dan sangat menentukan keberhasilan hasil belajar peserta didik.

Kurikulum pendidikan menjadi sebuah persepsi awal bagi guru dalam menjalankan perannya sebagai seorang pendidik. Marliany (2010: 187) berpendapat, "Persepsi dapat diartikan sebagai daya pikir dan daya pemahaman individu terhadap berbagai rangsangan yang datang dari luar." Persepsi terhadap implementasi kurikulum perlu diperhatikan oleh guru karena dalam kurikulum memuat pedoman pelaksanaan kegiatan belajar mengajar. Ketika persepsi guru terhadap 
implementasi kurikulum sudah baik, maka pelaksanaan kegiatan pembelajaran dapat sesuai dengan tujuan yang telah ditetapkan.

Revisi terhadap Kurikulum 2013

yang terjadi beberapa waktu terakhir dilakukan untuk memperbaiki sejumlah hal yang ada dalam Kurikulum 2013. Perubahan yang terjadi sebagai hasil dari revisi kurikulum tersebut perlu diperhatikan oleh guru. Dalam hasil penelitian ini ditemukan bahwa guru memiliki persepsi yang baik terhadap perubahan yang terjadi pada revisi Kurikulum 2013. Guru menyambut dengan sikap positif dan terbuka terhadap revisi kurikulum yang dilakukan oleh Kemendikbud tersebut. Dalam penelitiannya, Anwar (2014: 105) mengatakan bahwa hal mendasar yang perlu diperhatikan dalam pelaksanaan Kurikulum 2013 yaitu mempersiapkan diri terhadap pemberlakuan kebijakan dengan sikap terbuka. Dalam hasil wawancara penelitian ditemukan bahwa guru mengetahui dan memahami apa yang terjadi dalam Kurikulum 2013 Edisi Revisi di antaranya tentang materi pelajaran yaitu ada penambahan materi puisi dan resensi pada mata pelajaran bahasa Indonesia kelas X semester 2. Selain itu, dalam penilaian otentik terutama dalam penilaian sikap hanya diwajibkan bagi mata pelajaran Pendidikan Agama dan Pkn. Dalam Kurikulum 2013 Edisi Revisi pendekatan saintifik tidak banyak mengalami perubahan hanya terdapat penegasan tentang penerapan teori di dalam pembelajaran. Dari hasil penelitian ditemukan bahwa guru sudah berusaha menerapkan pendekatan saintifik dalam proses pembelajaran. Hal tersebut dibuktikan dengan hasil observasi yang menunjukkan penerapan kegiatan 5M yang dilakukan guru dalam kegiatan pembelajaran membaca puisi. Persepsi guru yang cukup baik tersebut juga ditunjukkan melalui Rencana Pelaksanaan Pembelajaran (RPP) yang disusun dengan cukup baik dan sesuai dengan pedoman dalam Permendikbud Nomor 22 Tahun
2016, pelaksanaan pembelajaran yang cukup baik dengan menggunakan pendekatan saintifik serta metode pembelajaran aktif sesuai dengan tuntutan dalam Permendikbud Nomor 22 Tahun 2016, dan penilaian pembelajaran yang sudah diupayakan untuk dilaksanakan, meskipun dengan segala keterbatasan waktu tatap muka pembelajaran yang tersisa.

\section{Perencanaan Pembelajaran Membaca Puisi}

Rencana Pelaksanaan Pembelajaran (RPP) menjadi pedoman bagi guru dalam pelaksanaan kegiatan belajar mengajar. Rencana Pelaksanaan Pembelajaran (RPP) disusun oleh guru melalui diskusi bersama dalam Musyawarah Guru Mata Pelajaran (MGMP). Namun dalam upaya pelaksanaan Rencana Pelaksanaan Pembelajaran (RPP) tersebut tetap ada perubahan yang dilakukan sesuai dengan situasi, kondisi, dan karakteristik siswa di sekolah masing-masing. Rencana Pelaksanaan Pembelajaran (RPP) disusun dengan baik dan sesuai dengan Permendikbud Nomor 22 Tahun 2016, meskipun ada beberapa komponen yang memiliki perbedaan dalam redaksi penulisan dengan yang ada dalam permendikbud. Rencana Pelaksanaan Pembelajaran (RPP) memiliki komponenkomponen yang perlu diisi sesuai dengan ketentuan yang telah ditetapkan. Ada 14 komponen yang terdapat dalam Rencana Pelaksanaan Pembelajaran (RPP) yang telah disusun oleh guru meliputi: (1) identitas sekolah; (2) mata pelajaran; (3) kelas/semester; (4) materi pokok; (5) alokasi waktu; (6) Kompetensi Inti (KI); (7) Kompetensi Dasar (KD) dan Indikator Pencapaian Kompetensi (IPK); (8) tujuan pembelajaran; (9) materi pembelajaran; (10) metode pembelajaran; (11) media pembelajaran; (12) sumber belajar; (13) langkah-langkah pembelajaran; penilaian hasil pembelajaran. 


\section{Pelaksanaan Pembelajaran Membaca Puisi}

Pelaksanaan pembelajaran membaca puisi dilakukan dengan tiga tahapan yaitu kegiatan pendahuluan, kegiatan inti, dan kegiatan penutup. Hal ini sesuai dalam Permendikbud Nomor 22 Tahun 2016 tentang Standar Proses Pendidikan Dasar dan Menengah dalam Bab IV mengenai Pelaksanaan Pembelajaran yang dikatakan bahwa pelaksanaan pembelajaran merupakan implementasi dari RPP, meliputi kegiatan pendahuluan, inti dan penutup. Pada kegiatan pendahuluan, guru memberikan pertanyaan-pertanyaan awal tentang puisi untuk menggali pengetahuan awal siswa terhadap puisi. Guru memberikan permodelan dalam membaca puisi dengan gaya dan ciri khas yang dimiliki oleh guru dan juga permodelan dari siswa dengan memberikan kesempatan bagi siswa untuk berani membaca puisi di depan kelas. Penyampaian materi menjadi menyenangkan melalui model pembelajaran permodelan tersebut.

Kegiatan inti pembelajaran terdiri dari 5 tahap kegiatan yaitu stimulation, problem statement, data processing, verification, dan generalization. Dalam kegiatan inti, guru juga menggunakan pendekatan saintifik. Berdasarkan hasil penelitian oleh Mustafa, dkk. (2015: 9) dikatakan bahwa pembelajaran yang menggunakan pendekatan saintifik membuat proses pembelajaran lebih menyenangkan, siswa aktif mengamati objek, aktif berdiskusi, aktif bertanya, dan aktif memberi tanggapan terhadap pendapat dari siswa yang lain maupun guru. Stimulation dilakukan dengan membaca dan memahami beberapa puisi yang terdapat dalam buku teks pegangan siswa. Problem statement dilakukan dengan instruksi dari guru yang ditujukan kepada siswa untuk membuat kelompok diskusi guna mengidentifikasi tema, isi, suasana, dan amanat yang terdapat dalam puisi yang digunakan sebagai bahan diskusi kelompok. Dalam penelitian yang dilakukan oleh Iswara (2016: 90) ditunjukkan bahwa ketika kelas dibagi dalam beberapa kelompok dan diberikan beberapa puisi maka siswa dapat mengkaji jeda, nada serta siswa juga dapat mengekspolasi ekspresi yang akan dilakukan saat membaca puisi. Data processing dilakukan dengan mengolah data temuan dari hasil identifikasi tema, isi, suasana, dan amanat yang terdapat dalam puisi tersebut. Kemudian, tahap verification dilakukan dengan presentasi hasil diskusi kelompok di depan kelas. Generalization dilakukan oleh guru dengan memberikan pembenaran dan ulasan terhadap jawaban dari pertanyaanpertanyaan yang muncul dalam kegiatan presentasi tersebut.

Kegiatan penutup berlangsung singkat dikarenakan keterbatasan waktu sehingga guru hanya dapat melakukan kegiatan evaluasi seluruh rangkaian aktivitas pembelajaran dan manfaat serta hasil-hasil yang diperoleh secara langsung maupun tidak langsung dari hasil pembelajaran yang telah berlangsung tersebut. Namun secara keseluruhan pelaksanaan pembelajaran membaca puisi sudah dilakukan dengan baik dan diupayakan sesuai dengan yang telah disusun dalam Rencana Pelaksanaan Pembelajaran (RPP).

\section{Penilaian Pembelajaran Membaca Puisi}

Penilaian dalam pembelajaran membaca puisi yang direncanakan dalam Rencana Pelaksanaan Pembelajaran (RPP) terdiri dari penilaian sikap, penilaian pengetahuan, dan penilaian keterampilan. Pada Kurikulum 2013 Edisi Revisi, penilaian sikap masih digunakan tetapi hanya pada Mata Pelajaran Pendidikan Agama dan Pkn.

\begin{tabular}{lcr}
\multicolumn{1}{c}{ Penilaian } & sikap dalam & Rencana \\
Pelaksanaan & Pembelajaran & (RPP) \\
menggunakan & teknik & penilaian \\
observasi/pengamatan, bentuk & penilaian
\end{tabular} berupa catatan hasil observasi, dan instrumen penilaian yang digunakan berupa jurnal. Penilaian pengetahuan dalam Rencana Pelaksanaan Pembelajaran 
(RPP) menggunakan teknik penilaian berupa tes. Bentuk penilaian berupa tes lisan (kuis) dan penugasan individu dan kelompok. Instrumen yang digunakan berupa kuis (daftar soal) dan lembar kerja. Penilaian keterampilan dalam Rencana Pelaksanaan Pembelajaran (RPP) pada pembelajaran membaca puisi menggunakan teknik penilaian penugasan. Bentuk penilaian berupa tugas tertulis. Instrumen penilaian berupa lembar kerja dan penililaian pembacaan puisi. Pada pelaksanaan penilaiain, guru tidak menggunakan semua rubrik penilaian yang termuat dalam Rencana Pelaksanaan Pembelajaran (RPP), guru mengambil sebuah keputusan dengan menjadikan tugas individu sebagai tugas kelompok. Hal tersebut dikarenakan waktu tatap muka pembelajaran yang sangat terbatas. Dalam hasil temuan penelitian yang dilakukan oleh Siraju (2015: 10) menunjukkan bahwa sistem penilaian dalam Kurikulum 2013 terlalu banyak mengandung indikator penilaian pada masing-masing aspek penilaian (sikap, pengetahuan, dan keterampilan) sedangkan alokasi waktu pada pelaksanaan pembelajaran hanya 45 menit dalam satu kali tatap muka pembelajaran dan guru dituntut untuk dapat melakukan evaluasi dan penilaian sekaligus dalam waktu singkat tersebut.

Rubrik penilaian pembelajaran membaca puisi sudah disusun dengan baik, jelas, dan terperinci serta sesuai dengan Permendikbud Nomor 23 Tahun 2016. Namun pada pelaksanaan penilaian pembelajaran membaca puisi belum dapat berjalan efektif karena keterbatasan waktu pembelajaran sehingga ada perubahan yang dilakukan guru dalam mengambil penilaian siswa dalam pembelajaran membaca puisi tersebut.

\section{Hambatan dalam Proses Pembelajaran Membaca Puisi}

Dalam pelaksanaan pembelajaran tentu ada beberapa hal yang tidak sesuai dengan yang telah direncanakan. Hal-hal yang di luar rencana itulah yang kemudian memunculkan hambatan atau kendala yang memberikan pengaruh dalam pelaksanaan pembelajaran. Hambatan muncul karena ada banyak hal yang mempengaruhi kegiatan pembelajaran. Hal-hal yang mempengaruhi kegiatan pembelajaran di antaranya guru, siswa, sarana prasarana, dan lingkungan. Namun justru dengan hadirnya hambatan-hambatan tersebut dapat menjadi bahan evaluasi pelaksanaan pembelajaran yang lebih baik. Waktu tatap muka pembelajaran yang terbatas menjadi hambatan utama dalam pelaksanaan pembelajaran membaca puisi. Dalam hasil penelitian yang dilakukan oleh Bintari, dkk. (2014) juga menunjukkan bahwa kendala yang dihadapi pada pelaksanaan pembelajaran bahasa Indonesia dengan pendekatan saintifik yaitu kesesuaian antara waktu yang disediakan dengan materi pembelajaran. Luasnya materi pelajaran tidak sebanding dengan alokasi waktu pembelajaran yang telah disediakan sehingga materi pelajaran tersebut terkadang tidak dapat terselesaikan secara keseluruhan.

Dalam pelaksanaan pembelajaran membaca puisi, ada beberapa hambatan yang muncul antara lain: a) waktu tatap muka pembelajaran di semester 2 yang ternyata kurang untuk melaksana sehingga ada materi yang tidak dapat tersampaikan di dalam kelas; b) pelaksanaan penilaian pembelajaran yang belum efektif karena terjadi perubahan penggunaan rubrik penilaian yang telah disusun dalam Rencana Pelaksanaan Pembelajaran (RPP) sebagai akibat dari waktu tatap muka pembelajaran yang terbatas; c) tidak semua siswa memiliki bakat dalam hal seni terutama seni membaca puisi dan siswa sulit menemukan suasana puisi; d) dalam melakukan penilaian terhadap pembelajaran sastra terutama pada kegiatan membaca puisi masih terpengaruh oleh faktor subjektivitas dari guru. 
Upaya dalam Mengatasi Hambatan Proses Pembelajaran Membaca Puisi

Hambatan yang muncul dalam pelaksanaan pembelajaran membaca puisi perlu mendapat perhatian oleh guru agar pembelajaran ke depan menjadi lebih baik. Hambatan yang muncul dalam proses pelaksanaan pembelajaran terkadang berbeda antara guru satu dengan yang lain. Upaya yang dilakukan untuk mengatasi hambatan dalam proses pembelajaran membaca puisi antara lain: a) pemberian tugas secara terstruktur maupun tak terstruktur sehingga siswa dapat secara mandiri memahami materi puisi; b) penggunaan tugas secara diskusi kelompok agar penilaian membaca puisi tetap bisa dilaksanakan secara keseluruhan; c) siswa diberi arahan untuk memperbanyak membaca referensi tentang penampilan membaca puisi; d) pembuatan kriteria penilaian dan berpedoman pada kriteria penilaian membaca puisi tersebut pada saat pengambilan penilaian. Upaya-upaya tersebut menunjukkan bahwa guru sudah cukup baik dalam mengatasi segala hambatan yang muncul pada implementasi Kurikulum 2013 Edisi Revisi dalam pembelajaran membaca puisi.

\section{SIMPULAN}

Berdasarkan hasil dan pembahasan penelitian mengenai implementasi Kurikulum 2013 Edisi Revisi dalam pembelajaran membaca puisi (studi kasus di kelas $\mathrm{X}$ IPS 1 SMA Negeri 1 Karanganyar), maka dapat disimpulkan sebagai berikut.

Pertama, persepsi guru terhadap implementasi Kurikulum 2013 Edisi Revisi dalam pembelajaran membaca puisi sudah baik. Hal tersebut ditunjukkan dengan sikap guru yang positif dan terbuka terhadap perubahan yang terjadi dalam revisi pada Kurikulum 2013. Guru mengetahui dan memahami perubahanperubahan yang ada dalam Kurikulum 2013 Edisi Revisi. Guru juga melakukan pekerjaan administrasi pembelajaran seperti penyusunan perencanaan pembelajaran, melakukan pelaksanaan pembelajaran dan penilaian pembelajaran yang disesuaikan dengan Kurikulum 2013 Edisi Revisi.

Kedua, perencanaan pembelajaran membaca puisi di SMA Negeri 1 Karanganyar sudah disusun dengan baik. Penyusunan Rencana Pelaksanaan Pembelajaran (RPP) tersebut sesuai dengan pedoman dalam Permendikbud Nomor 22 Tahun 2016. Namun ada beberapa komponen yang berbeda redaksi penulisan dengan yang telah diatur dalam permendikbud tersebut.

Ketiga, pelaksanaan pembelajaran membaca puisi di kelas X IPS 1 SMA Negeri 1 Karanganyar dilakukan dengan cukup baik. Pelaksanaan pembelajaran diupayakan sesuai dengan Rencana Pelaksanaan Pembelajaran (RPP) yang telah disusun, namun pada tahap penutup belum dapat berjalan secara efektif karena keterbatasan waktu pembelajaran. Meskipun demikian, pelaksanaan pembelajaran membaca puisi berlangsung dengan kondusif dan menyenangkan melalui penggunaan pendekatan saintifik, metode pembelajaran permodelan, ceramah, diskusi dan pemanfaatan sumber dan media pembelajaran yang sesuai dengan topik pembelajaran membaca puisi. Penilaian pembelajaran membaca puisi di kelas X IPS 1 SMA Negeri 1 Karanganyar belum dilakukan secara efektif. Pelaksanaan penilaian tidak dapat dilakukan sama dengan rubrik penilaian yang telah disusun dalam Rencana Pelaksanaan Pembelajaran (RPP). Guru melakukan beberapa perubahan dalam penggunaan rubrik penilaian tersebut. Hal tersebut disebabkan karena keterbatasan waktu tatap muka pembelajaran.

Keempat, hambatan dalam implementasi Kurikulum 2013 Edisi Revisi dalam pembelajaran membaca puisi di kelas X IPS 1 SMA Negeri 1 Karanganyar meliputi: (a) waktu tatap muka pembelajaran di semester 2 yang terbatas sehingga materi pelajaran puisi tidak dapat disampaikan secara keseluruhan; b) 
pelaksanaan penilaian pembelajaran yang kurang efektif; c) tidak semua siswa memiliki bakat dalam membaca puisi dan siswa sulit menemukan suasana puisi; d) subjektivitas dalam menilai pembelajaran sastra.

Kelima, upaya untuk mengatasi hambatan dalam implementasi Kurikulum 2013 Edisi Revisi dalam pembelajaran membaca puisi di kelas X IPS 1 SMA Negeri 1 Karanganyar meliputi: a)

\section{REFERENSI}

Abidin, Yunus. (2014). Desain Sistem Pembelajaran dalam Konteks Kurikulum 2013. Bandung: PT Refika Aditama.

Anwar, Rusliansyah. (2014). Hal-hal yang Mendasari Penerapan Kurikulum 2013. Humaniora, 5 (1), 97 - 106.

Basir, Udjang Pr.M. (Tanpa Tahun). Aspek 'Kesastraan dalam Kurikulum Bahasa Indonesia: Sejumlah Problematika Terstruktur. Dalam Sukatman, Arju, \& Akhmad (Eds.). Seminar Nasional Bahasa dan Sastra Indonesia dalam Konteks Global, 227-236, FKIP Universitas Jember.

Bintari, Ni Luh Gede R. P., dkk. (2014). Pembelajaran Bahasa Indonesia Berdasarkan Pendekatan Saintifik (Problem Based Learning) sesuai Kurikulum 2013 di Kelas VII SMP Negeri 2 Amlapura. e-Journal Program Pascasarjana Universitas Pendidikan Ganesha Program Studi Pendidikan Bahasa Indonesia, 3.

Iswara, Prana D. (2016). Pengembangan Materi Ajar dan Evaluasi pada Keterampilan Mendengarkan dan Membaca. Mimbar Sekolah Dasar, 3 (1), $89-97$.

Kurinasih, Imas \& Berlin S. (2014). Sukses Mengimplementasikan Kurikulum 2013: Memahami Berbagai Aspek Dalam Kurikulum 2013. Surabaya: Kata Pena. pemberian tugas secara terstruktur maupun tak terstruktur agar materi dapat tetap dipelajari siswa melalui tugas-tugas tersebut; b) penggunaan tugas secara diskusi kelompok agar penilaian membaca puisi tetap bisa dilaksanakan dengan keterbatasan waktu yang ada; c) siswa diharuskan untuk sering melihat referensi penampilan membaca puisi dari youtube; d) pembuatan kriteria penilaian.

Marliany, Rosleny. (2010). Psikologi Umum. Bandung: CV Pustaka Setia.

Mulyasa, E. (2014). Pengembangan dan Implementasi Kurikulum 2013. Bandung: PT Remaja Rosdakarya.

Mustafa, M. Nur, dkk. (2015). Implementasi Kurikulum 2013 di SMA Negeri 12 Kota Pekanbaru. Jurnal Bahas, 10 (1), 1 - 9.

Permendikbud Nomor 22 Tahun 2016 tentang Standar Proses Pendidikan Dasar dan Menengah.

Siraju, Riswan A. (2015). Implementasi Kurikulum 2013 Mata Pelajaran Bahasa Indonesia (Studi Kasus pada Siswa Kelas XI SMA Negeri 1 Bacan Timur dan SMA Negeri 2 Bacan Selatan, Kabupaten Halmahera Selatan). Diperoleh pada 22 Juni 2018 dari digilib.uns.ac.id. 